
\title{
25 Research Square \\ The Determinant of Health Insurance Ownership Among Pregnant Women in Indonesia
}

\section{Agung Dwi Laksono}

Kementerian Kesehatan Republik Indonesia Badan Penelitian dan Pengembangan Kesehatan

Ratna Dwi Wulandari ( $\nabla$ ratna-d-w@fkm.unair.ac.id )

Universitas Airlangga https://orcid.org/0000-0003-4365-5747

\section{Ratu Matahari}

Ahmad Dahlan University School of Public Health: Universitas Ahmad Dahlan Fakultas Kesehatan Masyarakat

\section{Research article}

Keywords: health knowledge, reproductive health knowledge, maternal health, pregnancy care, health insurance, risk pregnant woman.

Posted Date: October 6th, 2020

DOI: https://doi.org/10.21203/rs.3.rs-76612/v1

License: (c) (1) This work is licensed under a Creative Commons Attribution 4.0 International License. Read Full License

Version of Record: A version of this preprint was published at BMC Public Health on August 11th, 2021. See the published version at https://doi.org/10.1186/s12889-021-11577-z. 


\section{Abstract}

Background: Health insurance is one indicator of the readiness of pregnant women for the delivery process. The study was aimed at analyzing the determinants of health insurance ownership among pregnant women in Indonesia.

Methods: The study involved 2,542 pregnant women in Indonesia. The variables analyzed included type of place of residence, age group, education level, employment status, marital status, parity, wealth status, and know the danger signs of pregnancy. Determination of determinant by binary logistic regression.

Results: The results show that pregnant women with higher education were 3.349 times more likely than no education pregnant women to have health insurance. Pregnant women with wealth status in the middle category were 0.679 times more likely than the poorest pregnant women to have health insurance. Meanwhile, the richest pregnant women had 1.358 times more chances than the poorest pregnant women to have health insurance. Grande multiparous pregnant women were 1.544 times more likely than primiparous pregnant women to have health insurance. Pregnant women who know the danger signs of pregnancy were 1.416 times more likely than pregnant women who don't know the danger signs of pregnancy.

Conclusions: It concluded that 4 variables were proven as determinants of health insurance ownership in Indonesia. The four variables were education level, wealth status, parity, and know the danger signs of pregnancy.

\section{Background}

The use of antenatal care (ANC) is an important factor in reducing maternal mortality and infant mortality ${ }^{1}$. Maternal mortality is the most important part in determining the health status of an area, so this has become a point of attention in the Sustainable Development Goals (SDGs) program points 3.1 and $3.2^{2}$. The Indonesian government through the ministry of health recommends that pregnant women do ANC at least four times during their pregnancy in the 1st and 2nd trimesters once and in the 3rd trimester 2 times ${ }^{3}$. However, in some developing countries access to the use of ANC services is still very minimal. Indonesia itself is a country that is in the lower-middle-income position with the highest maternal mortality rate in the South-East Asia region ${ }^{4}$. Statistically, the maternal mortality rate in 2012 was at 359 cases per 100,000 live births and decreased in 2015 to 305 cases per 100,000 live births ${ }^{5}$.

Based on this condition, the Ministry of Health of the Republic of Indonesia initiated the birth insurance program (Jampersal) as an alternative solution for pregnant women who have economic difficulties to pay for ANC services, post-delivery services, and postpartum family planning ${ }^{6}$. However, in 2014 the birth insurance program was replaced with a national insurance program called the National Health Insurance $(\mathrm{NHI})$ which includes insurance services for outpatients and inpatients in health services as well as 
several private health services. NHI also includes ANC, childbirth, and postpartum services, to support the achievement of universal health coverage goals by $2019^{3}$.

Several studies explain that the lack of access to ANC for pregnant women is related to geographical conditions including distance to access services and the socioeconomic status of pregnant women 2,7,8. The reason for the cost is the strongest factor that encourages a pregnant woman to be reluctant to examine ANC services ${ }^{9,10}$. As a solution to this situation, a health insurance system was implemented as a mitigation measure for ANC services based on the reason for the high cost of care $6,11,12$. The success of the $\mathrm{NHI}$ program implementation can be seen from the distribution of recipients to the Indonesian people because the $\mathrm{NHI}$ concept is not only intended for the poor but is for the entire community. Insurance ownership is an important factor in being able to take advantage of ANC services in hospitals for poor women in urban areas ${ }^{13,14}$.

Several studies have also shown a positive impact on the use of insurance in increasing access to ANC services ${ }^{3,15-17}$. Other studies that have been conducted in Ghana, Indonesia and Rwanda have also shown positive results in the form of an increase in the number of access to ANC that is covered by health insurance, namely $8 \%$ in Ghana, $3 \%$ in Indonesia, and $11 \%$ in Rwanda ${ }^{2}$. However, gaps related to the use of health insurance are still visible. This is influenced by geographic factors related to distance and transportation costs. For example, the availability of health services in the western part of Indonesia is increasing faster than in the eastern part of Indonesia (Sulawesi to Papua), low levels of education are linked to poverty making it difficult to reach health services ${ }^{13}$. Based on these realities, this study aims to analyze the determinant of health insurance ownership among pregnant women in Indonesia.

\section{Methods}

\section{Data Source}

The study was conducted using secondary data from the 2017 Indonesian Demographic Data Survey (IDHS). The IDHS is a part of an international survey network part of the Demographic and Health Survey (DHS) series. Internationally, the implementation of DHS is under the control of the Inner City Fund (ICF). Sampling for The 2017 IDHS used the stratification and multistage random sampling method. The unit of analysis in this study was pregnant women in childbearing age (15-49 years). The sample size used was 2,542 pregnant women.

\section{Data Analysis}

The dependent variable in this study was health insurance ownership, which was divided into 2, namely having health insurance and not having. Meanwhile, the independent variables involved in the analysis of this study include the type of place of residence, age groups, education level, employment status, marital status, wealth status, parity, and know the danger signs of pregnancy. 
The type of place of residence was divided into 2 categories, namely urban and rural. The age group was divided at 5-year intervals into 7 groups. The education level consists of 4 strata, namely no education, primary, secondary, and higher. Employment status was divided into 2 categories, namely unemployed and employed. Marital status was divided into 3 categories, namely never in the union, married or living with a partner, and widowed or divorced. Wealth status was determined based on the wealth index calculation. The wealth index was a composite measure of a household's cumulative living standard. The wealth index was calculated using easy-to-collect data on a household's ownership of selected assets, such as televisions and bicycles; materials used for housing construction; and types of water access and sanitation facilities. Wealth index was divided into 5 categories, namely the poorest, poorer, middle, richer, and richest ${ }^{5}$. Parity was the number of children who have been born alive. Parity was divided into 3 categories, namely primiparous $(\leq 1)$, multiparous $(2-4)$, and grande multiparous $(>4)$. Know the danger of pregnancy was the respondent's knowledge of the dangers of prolonged labor, vaginal bleeding, fever, convulsions, baby in the wrong position, swollen limbs, faint, breathlessness, tiredness, and others. Know the danger of pregnancy was divided into 2 categories, namely "do not know" and "know". Respondents fall into the "know" category if they admit to knowing all the dangers of pregnancy.

In the early stages, a collinearity test was carried out to ensure that there was no collinearity between variables. Furthermore, all variables involved in the analysis of this study were dichotomous variables, therefore the chi-square test was used to select the variables to be involved in the final stage. In the final stage, binary logistic regression was used because of the nature of the dependent variable. All statistical analyzes were carried out using SPSS 22 software.

\section{Results}

The results for the collinearity test of health insurance ownership among pregnant women in Indonesia can be seen in Table 1. The results of the analysis indicate that there is no collinearity between the dependent and independent variables. The tolerance value of all variables as shown in Table 1 is greater than 0.10 . While the VIF value for all variables is less than 10.00 . Then referring to the basis of decision making in the multicollinearity test it can be concluded that there were no symptoms of multicollinearity in the regression model ${ }^{18}$. 
Table 1

Results for the collinearity test of health insurance ownership among pregnant women in Indonesia ( $n=2,542)$

\begin{tabular}{|lll|}
\hline VARIABLES & \multicolumn{2}{l|}{ COLLINEARITY STATISTICS } \\
\cline { 2 - 3 } & Tolerance & VIF \\
\hline Type of place of residence & 0.736 & 1.359 \\
\hline Age group & 0.722 & 1.385 \\
\hline Education level & 0.774 & 1.291 \\
\hline Employment status & 0.946 & 1.057 \\
\hline Marital status & 0.989 & 1.011 \\
\hline Wealth status & 0.622 & 1.607 \\
\hline Parity & 0.695 & 1.438 \\
\hline Know the danger signs of pregnancy & 0.926 & 1.080 \\
\hline *Dependent Variable: Health Insurance Ownership & \\
\hline
\end{tabular}

\section{Descriptive Results}

Descriptive statistics of health insurance ownership among pregnant women in Indonesia can be seen in Table 2. Table 2 informs that pregnant women are dominated by those who live in rural areas, whether they have health insurance or not. Based on the age group, the two categories of health insurance ownership were dominated by the 30-34 age group. 
Table 2

Descriptive statistic of health insurance ownership among pregnant women in Indonesia $(\mathrm{n}=2,542)$

\begin{tabular}{|c|c|c|c|c|c|}
\hline \multirow[t]{3}{*}{ CHARACTERISTICS } & \multicolumn{4}{|c|}{ HEALTH INSURANCE OWNERSHIP } & \multirow[t]{3}{*}{$\mathbf{P}$} \\
\hline & \multicolumn{2}{|l|}{ No } & \multicolumn{2}{|l|}{ Yes } & \\
\hline & $\mathrm{n}$ & $\%$ & $\mathbf{n}$ & $\%$ & \\
\hline Type of place of residence & & & & & 0.055 \\
\hline - Urban & 459 & $44.7 \%$ & 737 & $48.6 \%$ & \\
\hline - Rural & 567 & $55.3 \%$ & 779 & $51.4 \%$ & \\
\hline Age groups & & & & & $\star \star 0.006$ \\
\hline$-15-19$ & 9 & $0.9 \%$ & 9 & $0.6 \%$ & \\
\hline$-20-24$ & 91 & $8.9 \%$ & 108 & $7.1 \%$ & \\
\hline$-25-29$ & 269 & $26.2 \%$ & 370 & $24.4 \%$ & \\
\hline$-30-34$ & 308 & $30.0 \%$ & 472 & $31.1 \%$ & \\
\hline$-35-39$ & 284 & $27.7 \%$ & 430 & $28.4 \%$ & \\
\hline$-40-44$ & 54 & $5.3 \%$ & 123 & $8.1 \%$ & \\
\hline$-45-49$ & 11 & $1.1 \%$ & 4 & $0.3 \%$ & \\
\hline Education level & & & & & $\star \star * 0.000$ \\
\hline - No education & 23 & $2.2 \%$ & 17 & $1.1 \%$ & \\
\hline - Primary & 315 & $30.7 \%$ & 407 & $26.8 \%$ & \\
\hline - Secondary & 602 & $58.7 \%$ & 835 & $55.1 \%$ & \\
\hline - Higher & 86 & $8.4 \%$ & 257 & $17.0 \%$ & \\
\hline Employment status & & & & & $\star \star 0.005$ \\
\hline - Unemployed & 632 & $61.6 \%$ & 849 & $56.0 \%$ & \\
\hline - Employed & 394 & $38.4 \%$ & 667 & $44.0 \%$ & \\
\hline Marital status & & & & & 0.109 \\
\hline - Never in union & 0 & $0.0 \%$ & 3 & $0.2 \%$ & \\
\hline - Married/living with partner & 1017 & $99.1 \%$ & 1507 & $99.4 \%$ & \\
\hline - Widowed/divorced & 9 & $0.9 \%$ & 6 & $0.4 \%$ & \\
\hline
\end{tabular}

Note: $* \mathrm{p}<0.05 ; * * \mathrm{p}<0.01 ; * * * \mathrm{p}<0.001$ 


\begin{tabular}{|c|c|c|c|c|c|}
\hline \multirow[t]{3}{*}{ CHARACTERISTICS } & \multicolumn{4}{|c|}{ HEALTH INSURANCE OWNERSHIP } & \multirow[t]{3}{*}{$P$} \\
\hline & \multicolumn{2}{|l|}{ No } & \multicolumn{2}{|l|}{ Yes } & \\
\hline & $\mathbf{n}$ & $\%$ & $\mathrm{n}$ & $\%$ & \\
\hline Wealth status & & & & & $\star * * 0.000$ \\
\hline - Poorest & 321 & $31.3 \%$ & 468 & $30.9 \%$ & \\
\hline - Poorer & 212 & $20.7 \%$ & 270 & $17.8 \%$ & \\
\hline - Middle & 237 & $23.1 \%$ & 240 & $15.8 \%$ & \\
\hline - Richer & 135 & $13.2 \%$ & 235 & $15.5 \%$ & \\
\hline - Richest & 121 & $11.8 \%$ & 303 & $20.0 \%$ & \\
\hline Parity & & & & & $\star * 0.009$ \\
\hline - Primiparous & 282 & $27.5 \%$ & 415 & $27.4 \%$ & \\
\hline - Multiparous & 649 & $63.3 \%$ & 902 & $59.5 \%$ & \\
\hline - Grande multiparous & 95 & $9.3 \%$ & 199 & $13.1 \%$ & \\
\hline Know the danger signs of pregnancy & & & & & $\star * * 0.000$ \\
\hline - No & 425 & $41.4 \%$ & 470 & $31.0 \%$ & \\
\hline -Yes & 601 & $58.6 \%$ & 1046 & $69.0 \%$ & \\
\hline
\end{tabular}

Table 2 informs that based on the education level, the two categories of health insurance ownership are dominated by pregnant women who have secondary education. Meanwhile, based on employment, the two categories of health insurance ownership were dominated by unemployed pregnant women.

Base on wealth status and parity, pregnant women who have health insurance or not, are dominated by the poorest women and multiparous women. While base on the knowledge of the danger signs of pregnancy, dominated by pregnant women who claim to know all about the danger signs of pregnancy.

Figure 1 shows a combination of 3 variables, namely ownership of health insurance, education level, and knowledge of the danger signs of pregnancy. It appears that pregnant women who have a higher level of education tend to have a better knowledge of the danger signs of pregnancy. This trend also applies to health insurance ownership, especially for pregnant women with higher education.

\section{Multivariate Regression Analysis}

The result of binary logistic regression can be observed in Table 3. The test at this final stage is to determine the determinant of health insurance ownership among pregnant women in Indonesia. As a 
reference, the chosen category was "do not have health insurance".

Table 3

The result of binary logistic regression of health insurance ownership among pregnant women in Indonesia $(\mathrm{n}=2,542)$

\begin{tabular}{|c|c|c|c|c|}
\hline \multirow[t]{2}{*}{ PREDICTOR } & \multicolumn{4}{|c|}{ HEALTH INSURANCE OWNERSHIP } \\
\hline & Sig. & OR & Lower Bound & Upper Bound \\
\hline Age group: 15-19 & - & - & - & - \\
\hline Age group: $20-24$ & 0.714 & 1.201 & 0.452 & 3.189 \\
\hline Age group: $25-29$ & 0.710 & 1.199 & 0.462 & 3.109 \\
\hline Age group: $30-34$ & 0.654 & 1.246 & 0.476 & 3.259 \\
\hline Age group: $35-39$ & 0.682 & 1.225 & 0.465 & 3.228 \\
\hline Age group: $40-44$ & 0.256 & 1.802 & 0.652 & 4.982 \\
\hline Age group: $45-49$ & 0.327 & .471 & 0.105 & 2.119 \\
\hline Education level: No Education & - & - & - & - \\
\hline Education level: Primary & 0.077 & 1.842 & 0.937 & 3.620 \\
\hline Education level: Secondary & 0.066 & 1.884 & 0.960 & 3.698 \\
\hline Education level: Higher & $\star * 0.001$ & 3.349 & 1.631 & 6.877 \\
\hline Employment status: Unemployed & - & - & - & - \\
\hline Employment status: Employed & 0.244 & 1.109 & 0.932 & 1.319 \\
\hline Wealth status: Poorest & - & - & - & - \\
\hline Wealth status: Poorer & 0.272 & 0.874 & 0.688 & 1.111 \\
\hline Wealth status: Middle & $\star * 0.002$ & 0.679 & 0.533 & 0.866 \\
\hline Wealth status: Richer & 0.562 & 1.085 & 0.824 & 1.430 \\
\hline Wealth status: Richest & $\star 0.035$ & 1.358 & 1.021 & 1.805 \\
\hline Parity: Primiparous & - & - & - & - \\
\hline Parity: Multiparous & 0.755 & 0.967 & 0.782 & 1.195 \\
\hline Parity: Grande multiparous & $\star 0.014$ & 1.544 & 1.092 & 2.182 \\
\hline Know the danger signs of pregnancy: No & - & - & - & - \\
\hline Know the danger signs of pregnancy: Yes & $\star \star \star 0.000$ & 1.416 & 1.190 & 1.686 \\
\hline
\end{tabular}


Table 3 informs that there are four variables proven to be significant as a determinant of health insurance ownership among pregnant women in Indonesia. First, education level. Pregnant women with higher education are 3.349 times more likely than no education pregnant women to have health insurance (OR $3.349 ; 95 \% \mathrm{Cl} 1.631-6.877)$.

Second, wealth status. Pregnant women with wealth status in the middle category are 0.679 times more likely than the poorest pregnant women to have health insurance (OR $0.679 ; 95 \% \mathrm{Cl} 0.533-0.866$ ). Meanwhile, the richest pregnant women had 1.358 times more chances than the poorest pregnant women to have health insurance (OR 1.358; $95 \% \mathrm{Cl} 1.021-1.805)$.

Third, parity. Grande multiparous pregnant women are 1.544 times more likely than primiparous pregnant women to have health insurance (OR 1.544; $95 \% \mathrm{Cl} 1.092-2.182)$. It means grande multiparous pregnant women have a higher chance than the primiparous pregnant women to have health insurance.

Fourth, know the danger signs of pregnancy. Pregnant women who know the danger signs of pregnancy are 1.416 times more likely than pregnant women who don't know the danger signs of pregnancy (OR $1.416 ; 95 \%$ Cl 1.190-1.686).

\section{Discussion}

The analysis found that pregnant women with higher education had a higher chance of having health insurance than other levels of education. This information suggests that higher education provides a better understanding of the benefits of health insurance ${ }^{19,20}$. On the other hand, a better level of education also encourages pregnant women to later do childbirth to healthcare ${ }^{21}$. A study in South-east Nigeria informed that the main reasons cited by people who do not want to participate in health insurance mechanisms are a poor understanding of how the health care system works and a lack of a steady source of income 22 .

Generally, several previous studies have informed that better levels of education are positively related to the output of program performance in the health sector ${ }^{18,23-25}$. On the other hand, lower levels of education are a barrier to achieving better performance in the health sector ${ }^{26,27}$.

The results of the multivariate analysis found that wealth status is one of the determinants of health insurance ownership among pregnant women. This finding confirms the results of previous studies with the same research theme in Nigeria and Ghana which informed that those who have good wealth status are more likely to participate in health insurance ${ }^{22,28,29}$. Pregnant women with low wealth status probably do not have a fixed source of income. A pregnant woman or her husband has a type of job that is not permanent, making it difficult to set aside income to pay health insurance premiums ${ }^{22,30-32}$.

The results inform that the grande multiparous pregnant women have a higher probability than the primiparous pregnant women to have health insurance. This information indicates that pregnant women with parity in the grande multiparous category are aware of the high risk and dangers of having more 
than 4 pregnancies. Previous pregnancy experiences also have the potential to trigger awareness of greater risk in future pregnancies ${ }^{33}$, the risks are not only to pregnant women but also to their babies 34,35 .

Finally, pregnant women who know the danger signs of pregnancy have a better chance than pregnant women who don't know the danger signs of pregnancy. This finding is in line with the previous variable, parity. Better knowledge of the danger signs of pregnancy makes pregnant women more aware and better prepared for labor ${ }^{36-38}$.

The findings in this study are useful for policymakers who are responsible for the health financing system in Indonesia to increase the number of NHI participants, especially pregnant women. The results of the analysis provide a precise target, namely pregnant women who are low educated, poor, primiparous, and have low knowledge of the danger signs of pregnancy. Accelerating awareness-raising to participate in $\mathrm{NHI}$ in pregnant women could be directed at increasing their understanding of the risks of pregnancy and childbirth ${ }^{8,39}$.

\section{Conclusions}

Based on the research results, it could be concluded that 4 variables were proven to be determinants of health insurance ownership in Indonesia. The four variables were education level, wealth status, parity, and know the danger signs of pregnancy.

\section{Declarations}

\section{Ethics approval and consent to participate}

The 2017 IDHS has passed ethical clearance from the National Ethics Committee. The respondents' identities have all been deleted from the dataset. Respondents have provided written approval for their involvement in the study. The author has obtained permission for the use of data for this study through the website: https://dhsprogram.com/data/new-user-registration.cfm.

\section{Consent for publication}

Not applicable

\section{Competing interests}

The authors declare that they have no competing interests

\section{Funding}

Not applicable 


\section{Availability of data and materials}

Data cannot be shared publicly because of the data are owned by a third party and authors do not have permission to share the data. The 2017 IDHS data set name requested from the ICF ('data set of childbearing age women') are available from the ICF contact via https://dhsprogram.com/data/newuserregistration.cfm) for researchers who meet the criteria for access to confidential data.

\section{Authors' contributions}

ADL developed the proposal, analyzed and interpreted the patient data. RDW was a major contributor in conducting study, interpreting the data and writing the manuscript. RM was a major contributor in conducting study, interpreting the data and writing the manuscript. All authors read and approved the final manuscript.

\section{Acknowledgements}

The author would like to thank the ICF International, who has agreed to allow the 2017 IDHS data to be analyzed in this article.

\section{References}

1. Laksono AD, Rukmini R, Wulandari RD. Regional disparities in antenatal care utilization in Indonesia. PLoS One. 2020;15(2):e0224006.

2. Sanogo NA, Yaya S. Wealth Status, Health Insurance, and Maternal Health Care Utilization in Africa: Evidence from Gabon. Biomed Res Int. 2020;2020.

3. Anindya K, Lee JT, McPake B, Wilopo SA, Millett C, Carvalho N. Impact of Indonesia's national health insurance scheme on inequality in access to maternal health services: A propensity score matched analysis. J Glob Health. 2020;10(1):1-12.

4. Achadi EL. Kematian Maternal dan Neonatal di Indonesia. Rakerkernas 2019. 2019.

5. National Population and Family Planning Board, Statistics Indonesia, Ministry of Health, The DHS Program. Indonesia Demographic and Health Survey 2017 [Internet]. Jakarta; 2018. Available from: https://www.dhsprogram.com/pubs/pdf/FR342/FR342.pdf

6. Suparmi, Iram Barida Maisya HL. Health Insurance as a Solution for Barriers to Maternal Healthcare Access in Indonesia. Jakarta; 2019.

7. Suharmiati, Laksono AD, Astuti WD. Policy Review on Health Services in Primary Health Center in the Border and Remote Area (Review Kebijakan tentang Pelayanan Kesehatan Puskesmas di Daerah Terpencil Perbatasan). Bull Heal Syst Res. 2013;16(2):109-16.

8. Sukirman R, Wahyono TYM, Shivalli S. Determinants of healthcare facility utilization for childbirth in Kuantan Singingi regency, Riau province, Indonesia 2017. BMC Public Health. 2020;20(1):1-10. 
9. Yaya S, Da F, Wang R, Tang S, Ghose B. Maternal healthcare insurance ownership and service utilisation in Ghana: Analysis of Ghana demographic and health survey. PLoS One. 2019;14(4):1-13.

10. Aizawa T. The impact of health insurance on out-of-pocket expenditure on delivery in Indonesia. Health Care Women Int. 2019;40(12):1374-95.

11. Abu Bakar A, Samsudin S. Determinants of health care seeking behavior: Does insurance ownership matters? Int J Econ Financ Issues. 2016;6(7):6-11.

12. Müllerschön J, Koschollek C, Santos-Hövener C, Kuehne A, Müller-Nordhorn J, Bremer V. Impact of health insurance status among migrants from sub-Saharan Africa on access to health care and HIV testing in Germany: A participatory cross-sectional survey 11 Medical and Health Sciences 1117 Public Health and Health Services 11 Medical and Healt. BMC Int Health Hum Rights. 2019;19(1).

13. Nasution SK, Mahendradhata Y, Trisnantoro L. Can a National Health Insurance Policy Increase Equity in the Utilization of Skilled Birth Attendants in Indonesia? A Secondary Analysis of the 2012 to 2016 National Socio-Economic Survey of Indonesia. Asia-Pacific J Public Heal. 2020;32(1):19-26.

14. Wulandari RD, Laksono AD. "Are problems during pregnancy a predictor of childbirth in the hospital?" Determinants Analysis of Hospital Childbirth in Urban Poor Communities in Indonesia. 2019.

15. Mahendra IGAA, Wilopo SA, Sukamdi, Putra IGNE. The role of decision-making pattern on the use of long-acting and permanent contraceptive methods among married women in Indonesia. Eur $J$ Contracept Reprod Heal Care. 2019;24(6):480-6.

16. Miraldo M, Proppera C, Williams RI. The impact of publicly subsidised health insurance on access, behavioural risk factors and disease management. Soc Sci Med. 2018;217:135-51.

17. Nugraheni WP, Mubasyiroh R, Hartono RK. The influence of Jaminan Kesehatan Nasional (JKN) on the cost of delivery services in Indonesia. PLoS One. 2020;15(7):Article number e0235176.

18. Wulandari RD, Laksono AD. Determinants of knowledge of pregnancy danger signs in Indonesia. PLoS One. 2020;15(5):Article number e0232550.

19. Sisira Kumara A, Samaratunge R. Health insurance ownership and its impact on healthcare utilization: Evidence from an emerging market economy with a free healthcare policy. Int J Soc Econ. 2019;47(2):244-67.

20. Idris H, Satriawan E, Trisnantoro L. Determinant of health insurance ownership in the informal sector: A panel study from Indonesia family life survey. Adv Sci Lett. 2017;23(4):3582-5.

21. Tille F, Röttger J, Gibis B, Busse R, Kuhlmey A, Schnitzer S. Patients' perceptions of health system responsiveness in ambulatory care in Germany. Patient Educ Couns. 2019;102(1):162-71.

22. Alo CN, Okedo-Alex IN, Akamike IC. Determinants of willingness to participate in health insurance amongst people living with HIV in a tertiary hospital in South-East Nigeria. Niger Postgrad Med J. 2020;27(3):196-201.

23. Wulandari RD, Laksono AD. Education as predictor of the knowledge of pregnancy danger signs in Rural Indonesia. Int J Innov Creat Chang. 2020;13(1):1037-51. 
24. Ipa M, Widawati M, Laksono AD, Kusrini I, Dhewantara PW. Variation of preventive practices and its association with malaria infection in eastern Indonesia: Findings from community-based survey. PLoS One. 2020;15(5):e0232909.

25. Laksono AD, Wulandari RD, Efendi F. Determinants of hospital utilisation among urban poor societies in Indonesia. Int J Innov Creat Chang. 2020;12(9):375-87.

26. Laksono AD, Wulandari RD. The Barrier to Maternity Care in Rural Indonesia. J Public Heal From Theory to Pract. 2020;Online First.

27. Rohmah N, Yusuf A, Hargono R, Laksono AD, Masruroh, Ibrahim I, et al. Determinants of teenage pregnancy in Indonesia. Indian J Forensic Med Toxicol. 2020;14(3):2080-5.

28. Kusi A, Fenny A, Arhinful DK, Asante FA, Parmar D. Determinants of enrolment in the NHIS for women in Ghana - a cross sectional study. Int J Soc Econ. 2018;45(9):1318-34.

29. Williams GA, Parmar D, Dkhimi F, Asante F, Arhinful D, Mladovsky P. Equitable access to health insurance for socially excluded children? The case of the National Health Insurance Scheme (NHIS) in Ghana. Soc Sci Med. 2017;186:10-9.

30. Sari B, Idris H. Determinant of independent national health insurance ownership in Indonesia. Malaysian J Public Heal Med. 2019;19(2):109-15.

31. Wen C, Wallace JL. Toward human-centered urbanization? Housing ownership and access to social insurance among migrant households in China. Sustain. 2019;11(13):Article number 3567.

32. Kunpeuk W, Teekasap P, Kosiyaporn H, Julchoo S, Phaiyarom M, Sinam P, et al. Understanding the problem of access to public health insurance schemes among cross-border migrants in thailand through systems thinking. Int J Environ Res Public Health. 2020;17(14):1-19.

33. Zhang J, Mou Y, Liao J, Xiong H, Duan Z, Huang Y, et al. Uptake of maternal care and childhood immunization among ethnic minority and Han populations in Sichuan province: A study based on the 2003, 2008 and 2013 health service surveys. BMC Pregnancy Childbirth. 2019;19(1):Article number 250 .

34. Wulandari RD, Laksono AD. Is parity a predictor of neonatal death in Indonesia? Analysis of the 2017 Indonesia demographic and health survey. Indian J Forensic Med Toxicol. 2020;14(3):2161-6.

35. Laksono AD, Wulandari RD. Understanding Neonatal Death in Urban Area in Indonesia. Medico-Legal Updat. 2020;20(2):825-9.

36. Vijay NR, Kumare B, Yerlekar DS. Awareness of obstetric danger signs among pregnant women in tertiary care teaching hospital. J SAFOG. 2015;7(3):171-5.

37. Woldeamanuel GG, Lemma G, Zegeye B. Knowledge of obstetric danger signs and its associated factors among pregnant women in Angolela Tera District, Northern Ethiopia. BMC Res Notes. 2019;12(1):Article number 606.

38. Wassihun B, Negese B, Bedada H, Bekele S, Bante A, Yeheyis T, et al. Knowledge of obstetric danger signs and associated factors: a study among mothers in Shashamane town, Oromia region, Ethiopia. Reprod Health. 2020;17(1):4. 
39. Belay HG, Limenih MA. Intents of women on obstetric danger signs and its associated factors in Farta Woreda, Ethiopia, 2017. J Health Care Poor Underserved. 2020;31(1):140-52.

\section{Figures}

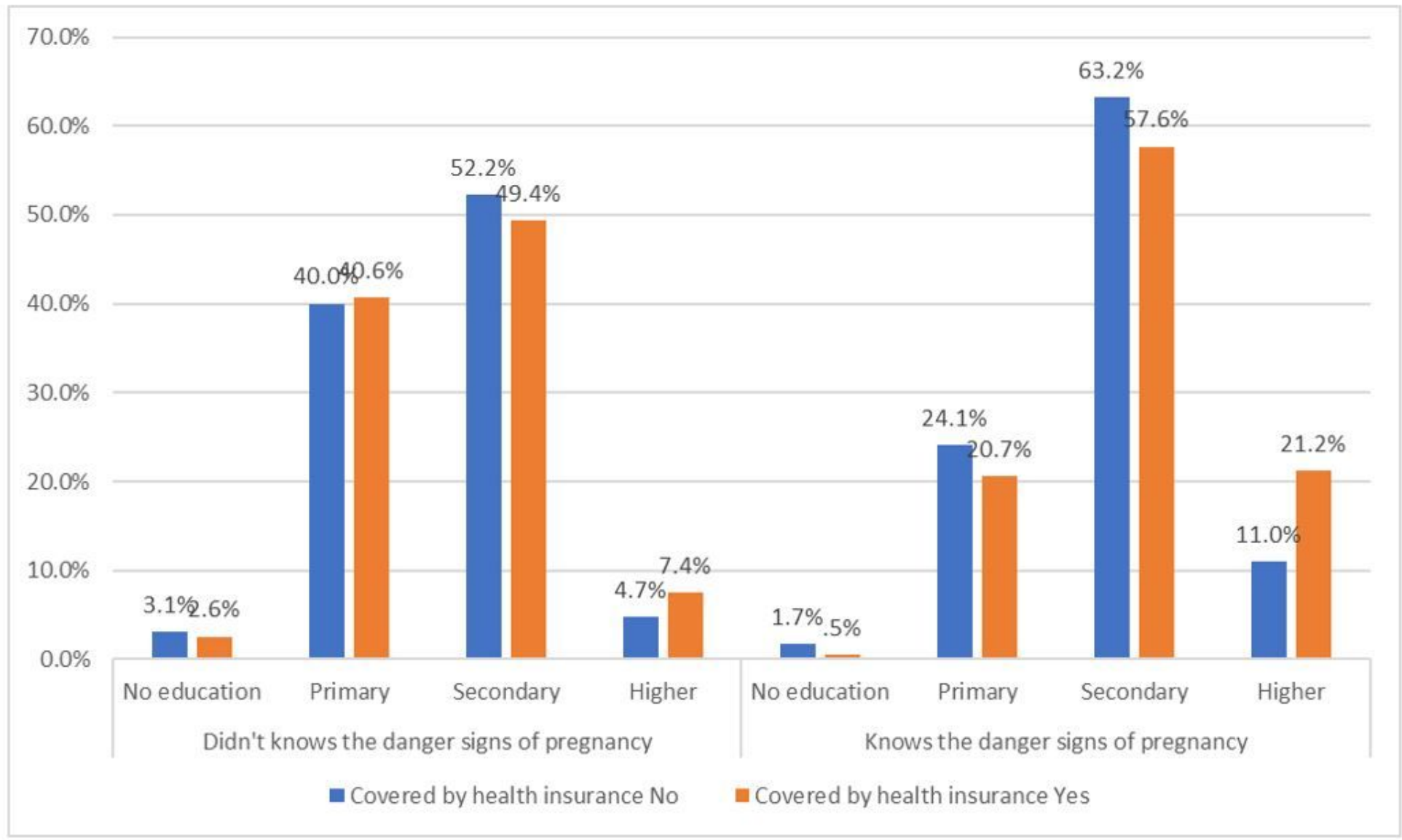

\section{Figure 1}

Distribution of Health Insurance Ownership of Pregnant Women by Education Level and Knowledge of the Danger Signs of Pregnancy in Indonesia, $2017(n=2,542)$ 